\title{
Trophic ecology of Trachurus mediterraneus juveniles associated with the jellyfish Rhizostoma pulmo and Cotylorhiza tuberculata
}

\author{
Joan Mir-Arguimbau*, Ana Sabatés, Uxue Tilves \\ Institut de Ciències del Mar, CSIC, Pg. Marítim de la Barceloneta 37-49, 08003 \\ Barcelona, Spain \\ *Corresponding author: Phone +34932309500 - FAX: +34 932309555 \\ joanmir@icm.csic.es
}

\begin{abstract}
This study analyses the trophic ecology of the horse mackerel (Trachurus mediterraneus) juveniles associated with two jellyfish species, Rhizostoma pulmo and Cotylorhiza tuberculata, in the NW Mediterranean. The aim was to know whether the natural diet composition of the hosted fish could be influenced by the jellyfish species and to explore if the fish could feed on the host jellyfish. Samplings were carried out off the coast of Barcelona in summer 2011 at depths of up to $10 \mathrm{~m}$. Juveniles associated with $C$. tuberculata showed a higher feeding incidence and number of ingested prey than those associated with $R$. pulmo. The relative importance of the different prey varied depending on the jellyfish species with which fish were associated. In juveniles associated with $C$. tuberculata, the diet was similar to the composition of the ambient zooplankton, with the cladocera Evadne spp. and Calanoida copepods as the most important prey. However, juveniles associated with $R$. pulmo fed mainly on Calanoida and Harpacticoida copepods. These differences could be related to the depth-associated behaviour of each jellyfish species, with $R$. pulmo particularly making deeper living plankton accessible to the horse mackerel juveniles. The presence of nematocyst cells in the juvenile gut contents suggests that they fed on the host jellyfish, either directly on the jellyfish tissue or accidentally when they remove the prey captured by the jellyfish oral arms. Our results provide a better understanding of the associations between jellyfish and juvenile fish which can have important effects on fish population dynamics.
\end{abstract}




\section{Keywords}

symbiosis, commensalism, horse mackerel juvenile, diet, nematocyst, NW Mediterranean

\section{Introduction}

Symbiotic interactions are common in nature and are important for sustaining species populations. The association between fish and jellyfish is a temporary commensalism and was described for the first time by Marteens (1671) (Karplus, 2014). Although fish-jellyfish association is considered facultative, the population dynamics of some fish species rely heavily on the abundance of jellyfish (Lynam \& Brierley, 2007). There are 96 fish families reported to be associated with floating objects and jellyfishes, especially those of the scyphozoan order, and the most common fish are Carangidae, Stromatidae and Gadidae (Purcell \& Arai, 2001). Even though interest in the relationships in the pelagic realm has recently increased (Ohtsuka et al., 2010), the significance of these interactions is poorly understood (Purcell \& Arai, 2001). Different hypotheses have been suggested to explain this association (reviewed in Mansueti, 1963; Arai, 1988; Purcell \& Arai, 2001): protection to juvenile fish from predation (e.g. Freon \& Dagorn, 2000), provisioning of food by feeding on the zooplankton captured by jellyfish (e.g. Masuda, 2009) or on the actual host jellyfish (e.g. D'Ambra et al., 2015), transportation to favourable areas (e.g. Castro et al., 2002; Masuda, 2009) and "meeting point" for school formation (e.g. Fréon \& Dagorn, 2000; Castro et al., 2002; Masuda, 2009). In the Mediterranean, different observations of fish sheltering underneath scyphozoan bells have been reported but very little is known about the trophic interactions between scyphozoan and their hosts and the effect of this association on fish recruitment (D’Ambra \& Malej, 2015). In particular, juveniles of Trachurus mediterraneus have been reported to be associated with floating objects (Massutí et al., 1999; Deudero \& Morales-Nin, 2001) and scyphozoan jellyfish such as Rhizostoma pulmo, Cotylorhiza tuberculata (D’Ambra \& Malej, 2015; Tilves et al., 2018) and Pelagia noctiluca (Sabatés et al., 2018).

R. pulmo and C. tuberculata are two of the most abundant coastal scyphozoan species in the northwestern Mediterranean during the summer period (Gili et al., 2009; Fuentes et al., 2011; D'Ambra \& Malej, 2015) and they can reach large numbers during blooming years (Mariottini \& Pane, 2010). Both species feed on planktonic organisms 
(Pérez-Ruzafa et al., 2002), and C. tuberculata has an autotrophic capacity due to the presence of zooxanthellae in the inner tissue (Leone et al., 2013). Although the interest in studying jellyfish has increased in recent years (Purcell et al., 2007), the ecology of this group and the relevance of the relationships between jellyfish and other organisms is still unknown (Karplus, 2014).

The Trachurus genus belongs to the Carangidae family (Perciformes) and is distributed throughout the Mediterranean Sea. Within this genus, the Mediterranean horse mackerel, Trachurus mediterraneus, is a semipelagic species that inhabits the continental shelf and is distributed throughout the Mediterranean and the northeastern Atlantic (Smith-Vaniz, 1986). In the Mediterranean, T. mediterraneus spawns during the spring and early summer (Karlou-Riga, 2000; Raya \& Sabatés, 2015), thus juveniles can be found in the pelagic environment in summer and early autumn. T. mediterraneus is a carnivorous species that feeds on zooplanktonic organisms (Deudero \& Morales Nin, 2001; Šantić et al., 2004; Fernández-Jover et al., 2007). However, there is a lack of information about the diet of juveniles associated with jellyfish.

This study aims to gain a deeper understanding of the ecological role of the association between fish and jellyfish. The specific goals were 1) to analyse the natural diet and feeding selectivity of T. mediterraneus juveniles associated with the jellyfish $R$. pulmo and C. tuberculata on the Catalan coast (NW Mediterranean), 2) to determine whether the diet composition of the hosted fish could depend on the jellyfish species, and 3) to explore if the fish could feed on the host jellyfish.

\section{Material and methods}

\subsection{Sample collection}

Sampling of jellyfish and their associated fish was conducted biweekly off Barcelona (NW Mediterranean; $41^{\circ} 23^{\prime} 2.4^{\prime \prime} \mathrm{N}, 2^{\circ} 12^{\prime} 17.1^{\prime \prime} \mathrm{E}$ in a radius of $20 \mathrm{~km}$ ), from July to September 2011, between 09:00 and 16:00 hours. Jellyfish together with their associated fish were collected from the boat using a hand net or by snorkelling near the surface at depths up to $10 \mathrm{~m}$. The jellyfish was identified and measured (bell diameter) and the hosted fish were immediately fixed in 5\% formaldehyde buffered with sodium tetraborate for species identification and size measurements (standard length \pm $\mathrm{SD})$. 
To assess potential juvenile fish prey selectivity, a monthly surface zooplankton for each jellyfish species was performed concurrently with the sampling of jellyfish and fish. We used a Bongo net of $40 \mathrm{~cm}$ mouth diameter equipped with paired cylindricalconical $200 \mu \mathrm{m}$ mesh nets, towed horizontally for $10 \mathrm{~min}$ at a vessel speed of 2 knots. The volume of water filtered by the nets was estimated by means of a flowmeter placed in the center of each net mouth. Samples were fixed in $5 \%$ formaldehyde buffered with sodium tetraborate for taxa identification and counting.

\subsection{Laboratory procedures}

A total of 104 individuals of T. mediterraneus, 58 associated with R. pulmo and 46 with $C$. tuberculata, were identified and examined for gut contents. Before dissection, the standard length (SL) and the lower jaw length (LJL) (measured from the tip to the junction with the maxilla), a functional proxy of mouth width, were determined under a stereo-microscope with an accuracy of $0.1 \mathrm{~mm}$. It should be noted that the fish mouth width is a determinant factor in the size of captured prey (Shirota 1970). The digestive tract, including stomach and gut, was dissected with fine needles and a scalpel and prey were identified to the lowest taxon possible. Families of the Calanoida order were differentiated; however, Clausocalanidae, Paracalanidae and Calanidae were grouped as "Clauso-Para-Calanidae". We measured the length and width of each prey to the nearest $0.01 \mathrm{~mm}$, excluding appendages and spines. For copepods, we measured the prosome and for the appendicularia and chaetognatha the trunk. When the degree of digestion did not allow the width of the prey to be measured, the relationship between length and width was used to estimate the real width of the prey. This estimation was only used for Evadne spp. and Clauso-Para-Calanidae, both of which were well represented in the zooplankton samples and in the stomach contents, and for which the length-width correlation was significant.

To explore the possible presence of nematocysts in the fish digestive tract, the stomach contents of 10 individuals of different sizes associated with each jellyfish species were analysed under a compound microscope. The digestive tracts were dissected as mentioned above, and the contents were spread on a slide using needles and a scalpel.

Zooplankton from the bongo net samples was classified into large functional groups using the prey categories chosen for diet analyses. Repeated aliquots of $10 \mathrm{~mL}$ 
(out of a $500 \mathrm{~mL}$ volume) were taken from each sample until we identified and counted between 850 and 1000 individuals per sample. We measured the length and width of 100-150 individuals per aliquot to the nearest $0.01 \mathrm{~mm}$. The abundances were standardized to number of individuals per $\mathrm{m}^{3}$ according to the volume of water filtered.

\subsection{Data analysis}

To test the similarity of the zooplankton community (average summer values) sampled with each jellyfish species and their associated fish, the Bray Curtis index of Similarity (Bray \& Curtis, 1957) was applied:

where $N i j$ is the standardized number of individuals of species $i$ in sample $j$, and Nik is the standardized number of individuals of species $i$ in the sample $k$. The relative mean abundance of the dominant zooplanktonic groups (higher than $3 \%$ ) for each jellyfish species was compared with a non-paired T-test, and with a Mann-Whitney U-test for non-parametric data.

The feeding incidence was calculated as the proportion of juveniles with prey in the gut. Diet composition was described as the numerical percentage (N\%) and the percentage of frequency of occurrence $(\mathrm{F} \%)$ of diet items in juveniles examined with prey in their guts. The product of $\mathrm{N} \%$ and $\mathrm{F} \%$ was taken as an Index of the Relative Importance (IRI) of each prey item and standardized to \%IRI to readily allow comparison (Young \& Davis, 1990). To assess ontogenetic changes in the diet, juveniles were separated into two size classes ( $\leq 30$ and $>30 \mathrm{~mm} \mathrm{SL}$ ) in order to obtain a minimum of 15 individuals per size-class.

The relationships between juvenile body measurements (SL and LJL) and prey number and average prey size per juvenile were determined by linear regression analysis and Spearman correlations.

The diversity of prey items was calculated using Levins' diet breadth index (Levins, 1968), where $p i$ is the proportion of each prey taxon in the diet: $B=\left(\Sigma p i^{2}\right)-1$.

The breadth of the prey-size niche was calculated using the SLH index (Pearre, 1986) by regressing the standard deviation of the log-transformed prey length versus the SL of fish. 
Possible differences in the diet composition between juveniles associated with $R$. pulmo and $C$. tuberculata were tested using a PERMANOVA on the Bray-Curtis resemblance matrix (999 permutations). When significant differences were detected, post hoc pairwise comparisons were calculated. SIMPER routine was applied to identify the prey taxa most responsible for these differences. The procedures were performed with PRIMER 6 + PERMANOVA (Clarke and Warwick, 2005; Anderson et al., 2008).

Prey taxon selectivity by juveniles was calculated by the $\alpha$ index (Chesson, 1978), from individuals collected concurrently with the sampling of environment zooplankton:

where $r k$ and $p k$ are the proportion of prey $\mathrm{k}$ in the diet and in the field, respectively, and $n$ is the number of prey taxa. We only considered prey taxa with a \% IRI higher than $0.8 \%$. The index was calculated individually for each juvenile and its concurrent zooplankton sample, and then averaged for the two fish size groups and for each jellyfish species. Neutral selection would result in a constant $\alpha=1 / n$, and statistical significance of $\alpha$ for prey taxon against the neutral selection was tested by one sample ttest. The statistical analyses were performed with SPSS Statistics 17.0 and SigmaPlot 12.5 .

\section{Results}

\subsection{Prey environment}

The ocean zooplankton community (average summer values) collected with each jellyfish species and their associated fish was dominated by cladocerans and copepods (Table 1). Among them, the cladocera Evadne spp. and the Clauso-Para-Calanidae copepods were the most abundant groups, representing more than $45 \%$ and $20 \%$, respectively. Other groups, such as Appendicularia, were also relatively abundant, accounting for $5.51 \%$. A high similarity was found between the zooplankton composition sampled with each jellyfish species $(\mathrm{BC}=81.7 \%)$, and no differences were found between the relative mean abundance of the dominant groups: Appendicularia (Mann-Whitney U-test, $\mathrm{P}=0,400$ ), Clauso-Para-Calanidae (Two-tailed T-test, $\mathrm{P}=$ 0,157), Evadne spp. (Mann-Whitney U-test, $\mathrm{P}=1,000$ ), P. avirostris (Two-tailed T-test, $\mathrm{P}$-value $=0,492)$. 


\subsection{Predator-prey relationships}

A total of $104 T$. mediterraneus juveniles were analysed, 46 associated with $5 C$. tuberculata $(13-18 \mathrm{~cm}$ bell diameter) and 58 with $17 \mathrm{R}$. pulmo $(14-52 \mathrm{~cm}$ bell diameter). The size range of fish associated with $R$. pulmo (11 - $61 \mathrm{~mm} \mathrm{SL})$ was larger than that of fish associated with C. tuberculata $(20-40 \mathrm{~mm} \mathrm{SL})$, and the most abundant size classes were between $20 \mathrm{~mm}$ and $40 \mathrm{~mm}$ SL (Fig.1).

The feeding incidence was high, $97.8 \%$ of juvenile fish associated with $C$. tuberculata and $86.2 \%$ associated with $R$. pulmo had prey in their guts. A total of 4798 prey items were found in the stomach contents. The average number of prey per gut was higher in juveniles associated with $C$. tuberculata than in those associated with $R$. pulmo (76.19 \pm 94.08 and $22.12 \pm 51.86$ respectively, $\mathrm{p}<0.001)$ (Fig. 2).

As juvenile jaw length was linearly related to $\mathrm{SL}\left(\mathrm{y}=0.218+0.01 \mathrm{x}, \mathrm{R}^{2}=0.689\right.$ $\mathrm{p}<0.001$ ), the different relationships between fish and prey number and size were explored using the juvenile SL to allow the comparison with most of published studies. The number of ingested prey was not related to the standard length of the juveniles and remained fairly constant in the fish size range examined $(\mathrm{Rho}=-0.233 \mathrm{p}=0.079$ for juveniles associated with $R$. pulmo, and $\mathrm{Rho}=0.313 \mathrm{p}=0.034$ for juveniles associated with C. tuberculata) (Fig. 2). No relationship was found between SL and average prey size of juveniles associated with $R$. pulmo $(\mathrm{Rho}=0.121 \mathrm{p}=0.429)$, although juveniles associated with $C$. tuberculata showed a weak but statistically significant correlation (Fig. 2) $(\mathrm{Rho}=0.396 \mathrm{p}=0.008)$. Breadth of the prey-size niche did not change significantly with juvenile SL $\left(y=-0.002 x+0.405 ; R^{2}=0.035\right.$ for juveniles associated with $R$. pulmo and $\mathrm{y}=0.003 \mathrm{x}+0.159 ; \mathrm{R}^{2}=0.129$ for juveniles associated with $C$. tuberculata).

Figure 3 shows the size spectra of ingested prey by juveniles of the two size classes ( $\leq 30 \mathrm{~mm}$ and $>30 \mathrm{~mm} \mathrm{SL}$ ) associated with $R$. pulmo and C. tuberculata (Fig. 3 $a, b)$, and the size spectra and taxonomic composition of the ocean zooplankton sampled with each jellyfish species (Fig. 3 c, d). Zooplankton size in the field ranged between $150 \mu \mathrm{m}$ and $1050 \mu \mathrm{m}$, and the most frequent classes were 550 and $650 \mu \mathrm{m}$ (Fig. 3c). Among juveniles $\leq 30 \mathrm{~mm}$ and associated with $R$. pulmo, the size of ingested prey ranged between $150 \mu \mathrm{m}$ and $1150 \mu \mathrm{m}$. The most abundant ingested size class was between $250-350 \mu \mathrm{m}$ (36.9\% of the total ingested prey), which corresponds with the 
size range of nauplii, gastropoda larvae and Corycaeidae copepods (Fig. 3c). Among larger juveniles $(>30 \mathrm{~mm})$ most ingested prey were also in the $250-350 \mu \mathrm{m}$ size range (26.9\%); however, larger prey (ranges 350-550 $\mu \mathrm{m}$ and 650-750 $\mu \mathrm{m}$ ) were also relatively important (Fig. 3a). The small prey, 150-250 $\mu \mathrm{m}$, composed mainly by nauplii and copepodites, were more important in juveniles $\leq 30 \mathrm{~mm}(16.4 \%)$.

Among fish associated with $C$. tuberculata, the most consumed prey ranged between 450 and $550 \mu \mathrm{m}(35.8 \%$ in $\leq 30 \mathrm{~mm}$ SL and $34.8 \%$ in $>30 \mathrm{~mm}$ SL) and corresponded to Evadne spp. and, to a lesser extent, to calanoid copepods (Fig. 3d). Again, smaller juveniles also consumed prey between 150 and $250 \mu \mathrm{m}$ (9.3\%), which corresponded to the size of nauplii, while juveniles $>30 \mathrm{~mm}$ showed higher consumption of prey between 550 and $850 \mu \mathrm{m}$, with percentages ranging between $10.4 \%$ and $17.6 \%$ (Fig. 3b).

\subsection{Diet Composition}

The juveniles were basically zooplanktivores and a broad diversity of prey types was found in their guts. Significant differences in the diet composition were found between juveniles associated with each jellyfish species, both in individuals $>30 \mathrm{~mm}$ (PERMANOVA pairwise comparison: $\mathrm{t}=3.24 \mathrm{P}($ perm $)=0.001)$ and in those $\leq 30 \mathrm{~mm}$ (PERMANOVA pairwise comparison: $\mathrm{t}=2.34, \mathrm{P}($ perm $)=0.001)$. SIMPER analysis indicated that the dissimilarity was mainly explained by Evadne spp., Clauso/Para/Calanidae and other Copepoda, both in individuals $>30 \mathrm{~mm}(61.08 \%$ of dissimilarity) and $\leq 30 \mathrm{~mm}(46.97 \%)$. In the diet composition of juveniles associated with $R$. pulmo, copepods were the dominant prey, representing $75.8 \%$ of IRI in individuals $\leq 30 \mathrm{~mm}$, and $87.1 \%$ in juveniles $>30 \mathrm{~mm}$. The Clauso-Para-Calanidae group represented $28.4 \%$ of IRI in the smaller size class and $11.5 \%$ in the larger class. However, the importance of the Harpaticoida order in the diet increased as the fish grew larger $(7.8 \%$ in juveniles $\leq 30 \mathrm{~mm}$ and $41.3 \%$ IRI in individuals $>30 \mathrm{~mm} \mathrm{SL})$. The copepodite stages were more important in the smaller size class $(29.2 \%$ IRI) than in the larger size class (6.9\% IRI). The cladoceran Evadne spp. constituted $10.6 \%$ of IRI in the smaller class and $0.5 \%$ of IRI in the larger class. Other prey such as mollusca Gastropoda and Bivalvia represented $10.1 \%$ and $2.4 \%$ of IRI, respectively, in smaller juveniles. Cirripeda larvae and Bivalva represented $9.2 \%$ and $2.3 \%$ of IRI, respectively, in the larger juveniles. 
In the diet of fish associated with $C$. tuberculata, copepods were also the dominant prey $(53 \%$ of IRI in juveniles $\leq 30 \mathrm{~mm}$ and $50.7 \%$ of IRI in juveniles $>30 \mathrm{~mm})$, but their relative importance was lower than that observed in juveniles associated with $R$. pulmo (Fig. 4). The Clauso-Para-Calanidae represented $24.1 \%$ and $25.3 \%$ of IRI in the smaller and larger juvenile sizes, respectively, the Harpacticoida order represented 0.7 $\%$ and $0.3 \%$, and copepodites represented $1.2 \%$ and $0.3 \%$ of IRI. The cladocera Evadne spp. was the dominant prey and represented $35.3 \%$ of IRI in juveniles $\leq 30 \mathrm{~mm}$ and $44.1 \%$ of IRI in individuals $>30 \mathrm{~mm}$. Other prey were not very abundant and only Bivalvia mollusca in the small juveniles represented $3.9 \%$ of IRI, similar to that observed in juveniles associated with $R$. pulmo. Overall, juveniles associated with $R$. pulmo showed a higher dietary diversity than those associated with $C$. tuberculata (Levin's index $B=8.55$ and $B=5.23$, respectively). The presence of nematocyst cells was detected in $50 \%$ of stomach contents of juveniles associated with C. tuberculata and in $70 \%$ of juveniles associated with $R$. pulmo (Fig. 5) in individuals from $11 \mathrm{~mm}$ to $56 \mathrm{~mm}$ SL.

\subsection{Prey selectivity}

Negative and positive selection for certain prey taxa was evident when the gut content of juveniles associated with $R$. pulmo was compared with the potential available prey (Fig. 6). Juveniles of the two size ranges showed negative selection for Temoridae copepods and the cladocera Evadne spp., while juveniles $>30 \mathrm{~mm}$ positively selected Harpacticoida copepods $(\mathrm{t}=4.1, \mathrm{p}<0.005)$. The two sizes of juveniles associated with $C$. tuberculata showed positive selection for Corycaeidae copepods and negative selection for Harpacticoida copepods and Gastropoda larvae (Fig. 6). In larger juveniles, a negative selection was observed for Temoridae copepods.

\section{Discussion}

The association between juvenile fish and jellyfish is temporary and restricted to a relatively short period in the life of the fish (Karplus, 2014). In our study, the size of $T$. mediterraneus associated with C. tuberculata and R. pulmo ranged between 11 and 61 $\mathrm{mm}$ SL; this last size corresponds to the juvenile pre-recruitment stage (Karlou-Riga, 2000). This size range fits that previously reported for different Trachurus species associated with jellyfish (Mansueti, 1963; Masuda, 2006; Tilves et al., 2018). The 
variability in the number and size of juveniles in association with jellyfish is highly dependent on the species of fish and jellyfish (Abel, 1962; Masuda, 2009). In our study, juveniles associated with $R$. pulmo showed a wider range of sizes than those associated with $C$. tuberculata. This wider range would be related with the larger umbrella of $R$. pulmo which would allow larger individuals to take refuge underneath it (Tilves et al., 2018).

Overall, T. mediterraneus juveniles showed a high feeding incidence, similar to that reported in juveniles of T. mediterraneus and Trachurus japonicus not associated with jellyfish (Deudero, 2001; Hirota et al., 2004), and higher than that reported in $T$. mediterraneus adults (Šantić et al., 2004; Yankova et al., 2008). In the present study, juveniles associated with $C$. tuberculata showed a higher feeding incidence (FI) and a higher number of ingested prey than those associated with R. pulmo. It should be considered that one of the benefits of the association between fish and jellyfish is the provisioning of food to the hosted fish by feeding on the zooplankton captured by jellyfish on their oral arms (Masuda et al., 2008; Masuda, 2009). Considering that the FI and the number of prey items per gut have been related to the abundance of preferred prey in the field (e.g. Koslow et al., 1985; Young \& Davis, 1990; Shoji \& Tanaka, 2006), possible differences in prey capture related to the distinct oral arm morphologies of the two jellyfish species (Mariottini \& Pane, 2010) that could help to explain the differences observed in the FI and the number of ingested prey. The possibility that $C$. tuberculata was less efficient at consuming the captured prey due to its autotrophic capacity which would increase the available zooplanktonic prey for the hosted fish, should also be considered.

Many studies conducted on larval and juvenile fish feeding have reported that prey size increases as the fish grow, while the size spectrum (niche breadth) remains constant (e.g. Munk, 1992; 1997; Pepin \& Penney, 1997; Sabatés \& Saiz, 2000; Sabatés et al., 2015), suggesting that juveniles replace small prey with larger prey as they develop. This strategy would allow larger fish to obtain more energetic prey and reduce the intraspecific feeding competition with small individuals (Pepin \& Penney, 1997; Morote et al., 2008). In the present study, we did not find a relationship between fish SL and prey size in juveniles associated with $R$. pulmo, while we observed a weak relationship in those associated with $C$. tuberculata. Comparing the size distribution of prey ingested by juveniles with the size spectra of zooplankton in the field, a preference 
for larger prey sizes was observed in the largest individuals while some differences were detected depending on the jellyfish species with which they were associated. In juveniles associated with $C$. tuberculata, the most frequently ingested prey size matched the most abundant zooplankton size, which corresponded to Evadne spp. and Calanoida copepods. On the other hand, juveniles associated with $R$. pulmo showed two peaks in the consumed prey sizes. The first peak corresponded to the smallest size ranges, mainly composed by Gastropoda larvae, Harpacticoida copepods and nauplii important groups in the juveniles' diet. Although these small organisms were not very abundant in the field, it is possible that they were not sampled efficiently. Accordingly, Calbet et al. (2001) reported that the abundance estimates of Eutherpina harpacticoida and Oithona cyclopoid were much lower when a $200 \mu \mathrm{m}$ mesh size was used compared to a $53 \mu \mathrm{m}$ net. The second peak coincided with the size range of Clauso-Para-Calanidae copepods, important prey for both juvenile size classes. For both host jellyfish species, the prey size spectra showed a displacement to larger sizes in the largest juveniles. Similar patterns were described by Munk et al. (1992) and Swalethorp et al. (2014) in Clupea harengus and Gadus morhua, respectively, though they found a positive relationship between fish SL and prey-size. Although these last studies considered similar fish sizes, specimens included individuals from larvae to juvenile stages with important morphological differences that can be expected to influence their foraging capability (Munk et al., 1992). Although the present study considered a wide range of fish sizes, all individuals were in the juvenile stage when these morphological changes are not so distinct.

Juveniles of $T$. mediterraneus mainly feed on Calanoida copepods and the cladoceran Evadne spp. The relative importance of copepods in the diet of $T$. mediterraneus has been previously reported in the Mediterranean (Deudero \& MoralesNin, 2001; Šantić et al., 2013). Unlike observations in these other studies, we did not find fish larvae or juveniles in the gut contents analyzed, probably because in these last studies the juveniles were larger and their diet was more similar to that of the adult stage when fish have a higher relative importance (Šantić et al., 2004; Bayhan et al., 2013). In any case, the relevance of Calanoida copepods and cladocerans has also been reported in the diet of larvae and juveniles of different fish species such as Engraulis encrasicolus and Sardina pilchardus during spring and summer in Mediterranean waters (Costalago et al., 2014). 
The relative importance of different prey varied depending on which jellyfish species the fish were associated with. The diet composition of juveniles associated with C. tuberculata was quite similar to that of the ambient surface zooplankton, and no significant differences were observed in the two fish size groups considered. The dominant groups in their diet, Evadne spp. and Calanoida copepods, were also the most abundant in the field and, together with the cladocera $P$. avirostris, constitute the typical summer period zooplanktonic community in Mediterranean surface waters (e.g. Calbet et al., 2001; Mazzocchi et al., 2011, Saiz et al., 2014). Previous studies have also documented that during the summer cladocerans make up a significant component of the diet of larvae of different fish species that dwell in surface waters (Catalán et al., 2007; 2011; Morote et al., 2008; 2010; Sabatés et al., 2015), playing an important role in the Mediterranean planktonic food web. Corycaeidae copepods were positively selected. This family of small copepods, and their development stages, have been reported as frequent prey of fish larvae (Turner, 1984; Catalan et al., 2007) and a positive selection for Corycaeidae copepods was also observed in anchovy during the summer in the study area (Costalago et al., 2014). A negative selection was found for Harpacticoida copepods and Gastropoda larvae. Negative selection for Harpacticoida, with respect to Calanoida copepods, was also observed in E. encrasicolus larvae (Conway et al., 1998; Catalán et al., 2010), which is in line with results of laboratory studies that showed that Calanoida led to higher anchovy larval growth rates than Harpacticoida copepods (Garrido et al., 2012). The prey composition of juveniles associated with $R$. pulmo differed to that of the ambient surface zooplankton. Their diet was more diverse than that of juveniles associated with $C$. tuberculata, and differences in the prey composition were observed between the two fish size groups. In the small size class, copepodites and Clauso-Para-Calanidae copepods were the most abundant prey, their importance decreasing as the fish grew, while the Harpaticoida order increased with fish size. Unlike the juveniles associated with $C$. tuberculata, both juvenile size classes associated with $R$. pulmo showed a positive selection for Harpacticoida copepods.

The differences in the diet composition of juveniles associated with each jellyfish species are presumably related to the jellyfish biology and behavior. $C$. tuberculata has symbiotic zooxanthellae in its endotermal tissue (Leone et al., 2013), and usually swims in the first $\sim 5$ meters of the water column (Tilves et al., 2018). 
Unlike C. tuberculata, $R$. pulmo have a wider vertical distribution (Tilves et al., 2018) and can perform active vertical movements, from the surface to near the bottom $(\sim 22-26$ $\mathrm{m}$, at depths of $28 \mathrm{~m}$ ) (Verwey, 1966). The wider vertical distribution of R. pulmo would explain the observed differences between the composition of juvenile diet and the surface zooplankton community, with a lower importance of Cladocera and a greater significance of Harpacticoida copepod, which have a deeper distribution, mainly below $20 \mathrm{~m}$ depth (Andersen et al., 2001). In addition, the wider vertical distribution of $R$. pulmo would favour a higher diversity of taxa in the juvenile diet. We must consider that selectivity analyses require a spatio-temporal match between the sampling of predators and prey (Dickmann et al., 2007). While jellyfish, their hosted fish, and environment zooplankton were sampled near the surface waters, the prey composition of juveniles associated with $R$. pulmo suggests that the selectivity results could be biased by the vertical displacements of this jellyfish. This could explain the different selectivity results found for Harpacticoida copepods in juveniles associated with each jellyfish species. Thus, the jellyfish species seems to determine the available prey to the juveniles, either feeding on the environment close to the jellyfish or on the prey captured by the jellyfish oral arms. Overall, the differences between the diet composition of juveniles associated with the two jellyfish species together with the results of the selection tests suggest that the juveniles are opportunistic predators.

Even though a large number of taxa was found in the stomachs of analysed juveniles, some of them, such as Siphonophora or gelatinous remains, could be underestimated due to their fast digestion rates (Revelles et al., 2007; Cardona et al., 2012; Logan \& Dodge, 2013). However, the presence of nematocysts in the stomach contents of T. mediterraneus suggests that juveniles fed on the host jellyfish, either directly on the jellyfish tissue or accidentally when they remove the prey captured by the jellyfish (Masuda et al., 2008). To the best of our knowledge, there was no evidence of the host tissue in the gut contents of Trachurus spp. Comparative analyses of three fish species, T. japonicus, Psenopsis anomala and Thamnaconus modestus, associated with jellyfish, showed that, while the two latter species contained jellyfish tissue and nematocysts in their stomachs, $T$. japonicus did not show traces of their hosts (Kondo et al., 2016; Miyajima et al., 2017). Recently Tilves et al. (2018), using stable isotope analyses, suggested that $R$. pulmo and $C$. tuberculata could constitute an important contribution to the diet of T. mediterraneus. We do not know to what extent the jellyfish 
can be an important part of the fish diet or if the fish can feed on the jellyfish when the abundance of planktonic prey in the field is scarce.

\section{Conclusions}

The present study reports, for the first time, the natural diet of T. mediterraneus juveniles in association with the jellyfish $R$. pulmo and C. tuberculata. Both jellyfish species, and their associated fish, were collected in surface waters. However, while the diet of juveniles associated with $C$. tuberculata was quite similar to that of the surface ambient zooplankton, with the cladocera Evadne spp. and Calanoida copepods as the most abundant prey, the diet of fish associated with $R$. pulmo was dominated by Calanoida and Harpacticoida copepods. These differences would be related to jellyfish biology since $C$. tuberculata remains in the upper levels of the water column, probably due to their photosynthetic capacity, while $R$. pulmo can perform vertical displacements, thus making prey from deeper waters available to the hosted fish. Nematocysts were found in the gut contents of T. mediterraneus juveniles, suggesting that they fed on the host jellyfish, either directly on the jellyfish tissue or accidentally when juveniles stole the prey captured by the jellyfish oral arms. These results highlight that fish-jellyfish trophic links within marine food webs may be more complex than previously thought. Defining better the associations between jellyfish and juvenile fish will help to understand the effects of the association on the survival and recruitment of ecologically and economically important fish species.

\section{Acknowledgments}

We are especially grateful to Josep Maria Gili for his advice in the identification of nematocyts. We also thank Vanesa Raya and Balbina Molí for their advice at the laboratory work.

Founding: This work was supported by the Spanish Ministry of Economy and Competitiveness (CTM2010-18874 and CTM2015-68543-R). JM was supported by a predoctoral FI-AGAUR fellowship of the University and Research Grants Management 
Agency (AGAUR) of the Government of Catalonia (Generalitat de Catalunya) (FI_B_00412).

\section{References}

Abel, E. F., 1962. Freiwasserbeobachtungen an Fischen im Golf von Neapel als Beitrag zur Kenntnis ihrer Ökologie und ihres Verhaltens. Int. Rev. gesamten Hydrobiol. 47, 219-290.

Andersen, V., Gubanova, A., Nival, P., Ruellet, T., 2001. Zooplankton community during the transition from spring bloom to oligotrophy in the open NW Mediterranean and effects of wind events. Vertical distributions and migrations. J. Plank. Res. 23, 243261.

Anderson, M.J., Gorley,R.N., Clarke,K.R., 2008. PERMANOVA + for PRIMER: Guide to Software and Statistical Methods. PRIMER-E, Plymouth, UK.

Arai, M.N., 1988. Interactions of fish and pelagic coelenterates. Can. J. Zool. 66, 19131927

Bayhan, B., Sever. T. M., Kara, A. 2013. Diet composition of the Mediterranean horse mackerel, Trachurus mediterraneus (Steindachner, 1868)(Osteichthyes: Carangidae), from the Aegean Sea. Bel. J. Zool. 143, 15-22.

Bray, J. R., Curtis, J. T., 1957. An ordination of the upland forest communities of southern Wisconsin. Ecol. Monogr. 27, 325-349.

Calbet, A., Garrido, S., Saiz, E., Alcaraz, M., Duarte, C.M., 2001. Annual zooplankton succession in coastal NW Mediterranean waters: the importance of the smaller size fractions. J. Plankton Res. 23, 319-331.

Cardona, L., Álvarez de Quevedo, I., Borrell, A., Aguilar, A. 2012. Massive consumption of gelatinous plankton by Mediterranean apex predators. PloS ONE 7: e31329.

Castro, J. J., Santiago, J. A, Santana-Ortega, A.Y., 2002. A general theory on fish aggregation to floating objects: an alternative to the meeting point hypothesis. Rev. Fish Biol. Fish. 11, 255-277. 
Catalán, I. A., Tejedor, A., Alemany, F., Reglero, P., 2011. Trophic ecology of Atlantic bluefin tuna Thunnus thynnus larvae. J. Fish. Biol.78, 1545-1560.

Catalán, I. A., Alemany, F., Morillas, A., Morales-Nin, B., 2007. Diet of larval albacore Thunnus alalunga (Bonnaterre, 1788) off Mallorca Island (NW Mediterranean). Sci. Mar. 71, 347-354.

Chesson, J., 1978. Measuring preference in selective predation. Ecology 59: 211-215.

Clarke, K.R., Warwick, R.M., 2005. Primer-6 Computer Program. Natural Environment Research Council, Plymouth.

Conway D. V. P., Coombs, S.H., Smith, C., 1998. Feeding of anchovy Engraulis encrasicolus larvae in the northwestern Adriatic Sea in response to changing hydrobiological conditions. Mar. Ecol. Prog. Ser. 175, 35-49.

Costalago, D., Palomera, I., Tirelli, V., 2014. Seasonal comparison of the diets of juvenile European anchovy Engraulis encrasicolus and sardine Sardina pilchardus in the Gulf of Lions. J. Sea Res. 89, 64-72.

D’Ambra, I., Malej, A., 2015. Scyphomedusae of the Mediteranean:State of the Art and Future Perspectives. Cent. Nerv. Syst. Agents Med. Chem. 15, 81-94.

D’Ambra, I., Graham W. M., Carmichael, R. H., Hernandez, F. J., 2015. Fish rely on scyphozoan hosts as a primary food source: evidence from stable isotope analysis. Mar. Biol. 162, 247-252.

Dahl, E., 1961. The association between young whiting, Gadus merlangus, and the jellyfish Cyanea capillata. Sarsia, 3, 47-55.

Deudero, S. 2001. Interspecific trophic relationships among pelagic fish species underneath FADs. J. Fish Biol. 58, 53-67.

Deudero, S., Morales-Nin, B., 2001. Prey selectivity in planktivorous juvenile fishes associated with floating objects in the western Mediterranean. Aquacult. Res. 32, 481490.

Dickmann, M., Möllmann, C., Voss, R., 2007. Feeding ecology of Central Baltic sprat Sprattus sprattus larvae in relation to zooplankton dynamics: implications for survival. Mar. Ecol. Prog. Ser. 342, 277-289. 
Fernandez-Jover, D., Jimenez, J. A. L., Sanchez-Jerez, P., Bayle-Sempere, J., Casalduero, F. G., Lopez, F. J. M., i Dempster, T. , 2007. Changes in body condition and fatty acid composition of wild Mediterranean horse mackerel (Trachurus mediterraneus, Steindachner, 1868) associated to sea cage fish farms. Mar. Environ. Res. 63: 1-18.

Fréon P., Dagorn L., 2000. Review of fish associative behaviour: Toward a generalisation of the meeting point hypothesis. Rev. Fish Biol. Fisher. 10, 183-207.

Fuentes V.L., Straehler-Pohl, I., Atienza, D., Franco, I., Tilves, U., Gentile, M., Acevedo, M., Olariaga, A., Gili, J.M., 2011. Life cycle of the jellyfish Rhizostoma pulmo (Scyphozoa: Rhizostomeae) and its distribution, seasonality and inter-annual variability along the Catalan coast and the Mar Menor (Spain, NW Mediterranean). Mar. Biol. 158, $2247-2266$

Garrido S., Saiz, E., Peters, J., Ré, P., Álvarez, P., Cotano, U., Herrero, E., Martínez de Murguía, A., Irigoien, X., 2012. Effect of food type and concentration on growth and fatty acid composition of early larvae of the anchovy (Engraulis encrasicolus) reared under laboratory conditions. J. Exp. Mar. Biol. Ecol., 434, 16-24

Gili J.M., Atienza, D., Fuentes, V., Lewinsky, I., 2009. Medusa project. Technical report to the Catalan Water Agency 2, $198 \mathrm{pp}$

Hirota Y., Uehara, S., Honda, H., 2004. Ontogenetic changes of feeding selectivity in juvenile jack mackerel Trachurus japonicus collected off south-east Kyushu, Japan. Fish. Sci. 70, 100-107.

Karlou-Riga C., 2000. Otolith morphology and age and growth of Trachurus mediterraneus (Steindachner) in the Eastern Mediterranean. Fish. Res. 46, 69-82.

Karplus I., 2014. The Associations between Fishes and Scyphozoan Medusae. In: Symbiosis in Fishes: The Biology of Interspecific Partnerships, First Edition. John Wiley \& Sons, Ltd, Chichster, pp. 212-229.

Kondo, Y., Ohtsuka, S., Hirabayashi, T., Okada, S., Ogawa, N. O., Ohkouchi, N., Shimazu, T., Nishikawa, J.N., 2016. Seasonal changes in infection with trematode species utilizing jellyfish as hosts: evidence of transmission to definitive host fish via medusivory. Parasite, 2016, 23, 16. 
Koslow, J. A., Brault, S., Dugas, J., Fournier R.O., Hughes, P., 1985. Condition of larval cod (Gadus morhua) off southwest Nova Scotia in 1983 in relation to plankton abundance and temperature. Mar. Biol. 86, 113-121.

Leone, A., Lecci R.M., Durante M., Piraino, S., 2013. Extract from the zooxanthellate jellyfish Cotylorhiza tuberculata modulates gap junction intercellular communication in human cell cultures. Mar. Drugs 11, 1728-1762.

Levins, R., 1968. Evolution in changing environments: some theoretical explorations, Princeton University Press, Princeton.

Logan, J. M., Dodge, K. L, 2013. Comment on "Stable isotopes challenge the perception of ocean sunfish Mola mola as obligate jellyfish predators”. J. Fish Biol. 82, 1-9.

Lynam, C. P., Brierley, A. S, 2007. Enhanced survival of 0-group gadoid fish under jellyfish umbrellas. Mar. Biol. 150, 1397-1401.

Mansueti, R, 1963. Symbiotic behavior between small fishes and jellyfishes, with new data on that between the stromateid, Peprilus alepidotus, and the scyphomedusa, Chrysaora quinquecirrha. Copeia: 40-80.

Mariottini G.L., Pane, L., 2010. Mediterranean jellyfish venoms: a review on Scyphomedusae. Mar. Drugs 8, 1122-1152.

Massutí, E., Morales-Nin, B., Deudero, S., 1999. Fish fauna associated with floating objects sampled by experimental and commercial purse nets. Sci., Mar. 63, 209-218.

Masuda R., 2006. Ontogeny of anti-predator behavior in hatchery-reared jack mackerel Trachurus japonicus larvae and juveniles: patchiness formation, swimming capability, and interaction with jellyfish. Fish. Sci. 72: 1225-1235.

Masuda, R., 2009. Ontogenetic changes in the ecological function of the association behavior between jack mackerel Trachurus japonicus and jellyfish. Hydrobiol. 616, 269277.

Masuda, R., Yamashita, Y., Matsuyama, M., 2008. Jack mackerel Trachurus japonicus juveniles use jellyfish for predator avoidance and as a prey collector. Fish. Sci. 74, 276284. 
Mazzocchi, M. G., Licandro, P., Dubroca, L., Di Capua. I., Saggiomo, V., 2011.

Zooplankton associations in a Mediterranean long-term time-series. J. Plank. Res. 33, $1163-1181$.

Miyajima-Taga, Y., Masuda, R., Yamashita, Y. 2017. Feeding capability of black scraper Thamnaconus modestus in giant jellyfish Nemopilema nomurai evaluated through field observations and tank experiments. Env. Biol. Fish. 100, 1237-1249.

Morote, E., Olivar M. P., Pankhurst, P.M., Villate, F., Uriarte, I., 2008. Trophic ecology of bullet tuna Auxis rochei larvae and ontogeny of feeding-related organs. Mar. Ecol. Prog. Ser. 353, 243-254.

Morote, E., Olivar, M. P., Villate, F., Uriarte, I., 2010. A comparison of anchovy (Engraulis encrasicolus) and sardine (Sardina pilchardus) larvae feeding in the Northwest Mediterranean: influence of prey availability and ontogeny. ICES J. Mar. Sci. 67, 1-12 Munk, P., 1992. Foraging behaviour and prey size spectra of larval herring Clupea harengus. Mar. Ecol. Prog. Ser. 80, 149-158.

Munk, P., 1997. Prey size spectra and prey availability of larval and small juvenile cod. J. Fish Biol. 51, 340-351.

Ohtsuka, S., Kondo, Y., Sakai, Y., 2010. In-situ observations of symbionts on medusae occurring in Japan, Thailand, Indonesia and Malaysia. Bulletin of the Hiroshima University Museum 2, 9- 18.

Pearre, S., 1986. Ratio-based trophic niche breadths of fish, the Sheldon spectrum, and the size efficiency hypothesis. Mar. Ecol. Prog. Ser. 27, 299-314.

Pepin, P., Penney R.W., 1997. Patterns of prey size and taxonomic composition in larval fish: are there general size: dependent models?. J. Fish Biol. 51, 84-100.

Perez-Ruzafa A., Gilabert, J., Gutiérrez, J.M., Fernández, A.I., Marcos, C., Sabah, S. 2002. Evidence of a planktonic food web response to changes in nutrient input dynamics in the Mar Menor coastal lagoon, Spain. Hydrobiol. 475, 359-369

Purcell, J.E., Arai, M.N., 2001. Interactions of pelagic cnidarians and ctenophores with fish: a review. Hydrobiol. 451, 27-44. 
Purcell, J.E., Uye S.I., Lo, W.T., 2007. Anthropogenic causes of jellyfish blooms and their direct consequences for humans: a review. Mar. Ecol. Prog. Ser. 350, 153-174.

Raya, V., Sabatés, A., 2015. Diversity and distribution of early life stages of carangid fishes in the northwestern Mediterranean: responses to environmental drivers. Fish. Oceanogr. 24, 118-134

Revelles, M., Cardona, L., Aguilar, A., Fernández, G., 2007. The diet of pelagic loggerhead sea turtles (Caretta caretta) off the Balearic archipelago (western Mediterranean): relevance of long-line baits. J. Mar. Biol. Assoc. UK 87, 805-813.

Sabatés, A., Saiz, E., 2000. Intra-and interspecific variability in prey size and niche breadth of myctophiform fish larvae. Mar. Ecol. Prog. Ser. 201, 261-271.

Sabatés, A., Zaragoza, N., Raya, V., 2015. Distribution and feeding dynamics of larval red mullet (Mullus barbatus) in the NW Mediterranean: the important role of cladocera. J. Plank. Res. 37, 820-833.

Sabatés, A., Salat, J., Tilves, U., Raya, V., Purcell, J.E., Pascual, M., Gili, J.M., Fuentes, V.L., 2018. Pathways for Pelagia noctiluca jellyfish intrusions onto the Catalan shelf and their interactions with early life fish stages. J. Mar. Syst. 187, 52-61

Saiz, E., Sabatés, A., Gili, J.M., 2014. The zooplankton. in: Goffredo, S., Dubinsky, Z. (Eds.), The Mediterranean Sea: Its History and Present Challenges. Springer, pp. 183-211.

Šantić, M., Jardas, I., Pallaoro, A., 2004. Diet composition and feeding intensity of Mediterranean horse mackerel, Trachurus mediterraneus (Osteichthyes: Carangidae) in the central Adriatic Sea. Acta Adriat. 45, 43-50.

Šantić, M., Rada, B., Pallaoro, A., 2013. Diet of juveniles Mediterranean horse mackerel, Trachurus mediterraneus and horse mackerel, Trachurus trachurus (Carangidae), from the eastern central Adriatic. Cah. Biol. Mar. 54, 41-48.

Shirota, A.,1970. Studies of the mouth size of fish larvae. Bull. Jpn. Soc Fish.

Oceanogr. 36: 353-368

Shoji J., Tanaka, M., 2006. Growth-selective survival in piscivorous larvae of Japanese Spanish mackerel Scomberomorus niphonius: early selection and significance of ichthyoplankton prey supply. Mar. Ecol. Prog. Ser. 321, 245 -254. 
Smith-Vaniz, W.F., 1986. Carangidae, in: Whitehead P.J.P., Bauchot, M.L., Hureau J.C., Nielsen, J., Tortonese E. (Eds), Fishes of the Northeastern Atlantic and the Mediterranean. Poissons de l'Atlantique du Nord-Est et de la Méditerranée II. UNESCO, Paris, pp. 815-844.

Swalethorp, R., Kjellerup, S., Malanski, E., Munk, P., Nielsen, T.G., 2014. Feeding opportunities of larval and juvenile cod (Gadus morhua) in a Greenlandic fjord: temporal and spatial linkages between cod and their preferred prey. Mar. Biol. 161, $2831-2846$.

Tilves, U., Sabatés, A., Blázquez, M., Raya, V., Fuentes, V.L. 2018. Associations between fish and jellyfish in the NW Mediterranean. Mar. Biol. 165, 127

Tolley, S. G., 1987. Association of young Chloroscombrus chrysurus (Pisces:

Carangidae) with the jellyfish Aurelia aurita. Copeia, 1987, 216-219.

Turner J. T., 1984. The feeding ecology of some zooplankters that are important prey items of larval fish. NOAA Tech. Rep. NMFS 7, 1-28.

Verwey, J., 1966. The role of some external factors in the vertical migration of marine animals. Neth. J. Sea Res. 3, 245-266.

Yankova, M.H., Raykov, V.S., Frateva, P.B., 2008. Diet composition of horse mackerel, Trachurus mediterraneus ponticus Aleev, 1956 (Osteichthyes: Carangidae) in the Bulgarian Black Sea waters. Turk. J. Fish. Aquat. Sci. 8, 321-327.

Young, J.W., Davis, L.O., 1990. Feeding ecology of larvae of southern bluefin, albacore and skipjack tunas (Pisces: Scombridae) in the eastern Indian Ocean. Mar. Ecol. Prog. Ser. 61, 17-29.

\section{Figure captions}

Fig. 1. Length frequency distribution of Trachurus mediterraneus juveniles associated with the jellyfish Rhizostoma pulmo and Cotylorhiza tuberculata.

Fig. 2. Relationships between Trachurus mediterraneus juveniles standard length and prey number per gut (upper panel) and mean prey size (+SD) per gut (lower panel) associated with Rhizostoma pulmo and Cotylorhiza tuberculata. 
Fig. 3. Size spectra of ingested prey by smaller (continuous line) and larger (dashed line) Trachurus mediterraneus juveniles associated with Rhizostoma pulmo (a) and Cotylorhiza tuberculata (b), and the size spectra and taxonomic composition by size range of ambient zooplankton sampled with Rhizostoma pulmo (c) and Cotylorhiza tuberculata $(\mathrm{d})$.

Fig. 4. Diet composition of Trachurus mediterraneus, associated with Cotylorhiza tuberculata and Rhizostoma pulmo, by size class, expressed as percent of the index of relative importance (\%IRI, see methods). The average summer composition of the ambient zooplankton is expressed as percentage.

Fig. 5. Images of nematocyst cells from analysed Trachurus mediterraneus stomachs.

Fig. 6. Mean Chesson's $\alpha$ values ( \pm standard error) for the most common prey items in Trachurus mediterraneus associated with Rhizostoma pulmo and Cotylorhiza tuberculata by juvenile size class. The horizontal lines represent the neutral values $(\alpha)$, values above and below the line indicate positive and negative selection, respectively. Significant values $(\mathrm{p}<0.05)$ are represented with $(*)$.

Table 1 Composition of the summer zooplankton community sampled with each jellyfish species: Mean abundance (ind $/ \mathrm{m}^{3} \pm \mathrm{SD}$ ) and relative abundance (\%) of different taxa.

\section{Zooplankton sampled with $R$. Pulmo}

Arthropoda

Cladocera

$$
\begin{aligned}
& \text { Evadne spp. } \\
& \text { Penilia avirostris }
\end{aligned}
$$

Copepoda

Calanoida

Centropagidae
Clauso-Para-
Calanidae
Pontellidae
Temoridae

Harpacticoida

Poecilostomatoida

Corycaeidae

Cyclopoida

Oithonidae

$\begin{array}{ll}560.69 & \pm 213.28 \\ 257.70 & \pm 113.53\end{array}$

$\mathrm{N}^{\mathbf{0}}$ ind $/ \mathrm{m}^{3}$
Desv.Est.
Zooplankton sampled with $C$. tuberculata

$\mathrm{N}^{\circ}$ ind $/ \mathrm{m}^{3} \quad$ Desv.Est. \% 


\begin{tabular}{|c|c|c|c|c|c|c|}
\hline Copepodite & 3.22 & \pm 5.53 & 0.13 & 3.00 & \pm 5.19 & 0.12 \\
\hline Nauplii & 4.92 & \pm 3.00 & 0.18 & 5.99 & \pm 5.19 & 0.24 \\
\hline Cirripeda larvae & 0.04 & \pm 0.00 & 0.00 & 0.00 & \pm 0.00 & 0.00 \\
\hline Decapoda & 1.14 & \pm 0.00 & 0.06 & 0.90 & \pm 0.00 & 0.04 \\
\hline Chaetognatha & 0.73 & \pm 1.27 & 0.02 & 0.00 & \pm 0.00 & 0.00 \\
\hline \multicolumn{7}{|l|}{ Chordata } \\
\hline \multicolumn{7}{|l|}{ Thaliacea } \\
\hline Doliolida & 209.01 & \pm 123.29 & 7.19 & 3.00 & \pm 5.19 & 0.12 \\
\hline Tunicata & & & & & \pm & \\
\hline Appendicularia & 99.92 & \pm 54.44 & 4.31 & 137.87 & \pm 88.25 & 5.51 \\
\hline \multicolumn{7}{|l|}{ Vertebrata } \\
\hline Fish larvae & 2.00 & \pm 1.73 & 0.08 & 5.99 & \pm 5.19 & 0.24 \\
\hline Fish egg & 1.49 & \pm 0.00 & 0.07 & 1.08 & \pm 0.00 & 0.04 \\
\hline Dinoflagellata & 125.91 & \pm 75.70 & 4.40 & 5.99 & \pm 5.19 & 0.24 \\
\hline \multicolumn{7}{|l|}{ Mollusca } \\
\hline Gastropoda & 2.66 & \pm 2.60 & 0.25 & 5.99 & \pm 5.19 & 0.23 \\
\hline Bivalvia & 1.00 & \pm 1.73 & 0.04 & 3.00 & \pm 5.19 & 0.12 \\
\hline Pteropoda & 7.95 & \pm 8.80 & 1.80 & 14.99 & \pm 18.72 & 0.60 \\
\hline Phoronida & 5.83 & \pm 6.24 & 0.23 & 17.50 & \pm 18.72 & 0.70 \\
\hline Polychaeta & 0.73 & \pm 1.27 & 0.02 & 0.00 & \pm 0.00 & 0.00 \\
\hline Siphonophorae & 2.06 & \pm 3.87 & 0.58 & 3.00 & \pm 5.19 & 0.97 \\
\hline
\end{tabular}

Table 2 Diet composition of Trachurus mediterraneus juveniles associated with Rhizostoma pulmo and Cotylorhiza tuberculata: percent of the total number of dietary items $(\% \mathrm{~N})$; percent frequency of occurrence of a dietary item $(\% \mathrm{~F})$; Index of relative importance (IRI) $(\% \mathrm{~N} * \% \mathrm{~F})$. The IRI was standardized to \%IRI.

Juveniles associated Juveniles associated with R. pulmo $\quad$ with C. tuberculata

$\%$ \%FO $\%$ IRI $\%$ N $\%$ FO

Arthropoda

$\begin{array}{ccccccc}\text { Cladocera Evadne spp. } & 8.7 & 24.1 & 5.4 & 34.0 & 84.8 & 40.4 \\ \text { Podon sp. } & 0.1 & 1.7 & 0.0 & 0.0 & 0.0 & 0.0 \\ \text { Penilia avirostris } & 0.7 & 10.3 & 0.2 & 0.4 & 10.9 & 0.1 \\ \begin{array}{c}\text { Unidentified Cladocera } \\ \text { Copepoda }\end{array} & 0.2 & 5.2 & 0.03 & 5.8 & 58.7 & 4.8 \\ \text { Calanoida } & & & & & & \\ \text { Clauso-Para-Calanidae } & 16.6 & 51.7 & 22.4 & 22.8 & 80.4 & 25.7 \\ \text { Centropagidae } & 0.0 & 0.0 & 0.0 & 0.3 & 10.9 & 0.0 \\ \text { Pontellidae } & 0.0 & 0.0 & 0.0 & 2.7 & 37.0 & 1.4 \\ \text { Temoridae } & 0.5 & 8.6 & 0.1 & 3.2 & 41.3 & 1.9 \\ \text { Unidentified Calanoida } & 3.5 & 27.6 & 2.5 & 7.8 & 71.7 & 7.9\end{array}$


Harpacticoida

Poecilostomatoida

Corycaeidae

Oncaeidae

Cyclopoida

Oithonidae

Copepodite

Nauplii

Unidentifiable Copepoda

Cirripedia larvae

Decapoda

Unidentified Arthropoda

Chaetognatha

Chordata

Tunicata

Appendicularia

Vertebrata

Fish egg

Mollusca

Gastropoda

Bivalvia

Pteropoda

Phoronida

Polychaeta

Gelatinous remains

Siphonophorae

Tintinida

Terrestrial plant trichoma $\begin{array}{llllll}16.8 & 48.3 & 21.2 & 1.2 & 26.1 & 0.4\end{array}$

$\begin{array}{llllll}9.0 & 41.4 & 9.7 & 3.0 & 60.9 & 2.6\end{array}$

$\begin{array}{llllll}0.8 & 12.1 & 0.2 & 0.7 & 28.3 & 0.3\end{array}$

$\begin{array}{llllll}0.1 & 1.7 & 0.004 & 0.0 & 2.2 & 0.0\end{array}$

$\begin{array}{llllll}17.4 & 48.3 & 21.9 & 1.3 & 37.0 & 0.7\end{array}$

$\begin{array}{llllll}0.4 & 8.6 & 0.1 & 1.0 & 17.4 & 0.3\end{array}$

$\begin{array}{llllll}4.4 & 39.7 & 4.5 & 10.0 & 82.6 & 11.6\end{array}$

$\begin{array}{llllll}3.8 & 32.8 & 3.3 & 0.0 & 0.0 & 0.0\end{array}$

$\begin{array}{llllll}0.0 & 0.0 & 0.0 & 0.5 & 13.0 & 0.1\end{array}$

$\begin{array}{llllll}0.1 & 1.7 & 0.004 & 0.1 & 4.3 & 0.0\end{array}$

$\begin{array}{llllll}0.0 & 0.0 & 0.0 & 0.3 & 4.3 & 0.0\end{array}$

$\begin{array}{llllll}0.9 & 8.6 & 0.2 & 0.1 & 2.2 & 0.0\end{array}$

$\begin{array}{llllll}0.1 & 1.7 & 0.00 & 0.8 & 34.8 & 0.4\end{array}$

$\begin{array}{llllll}8.8 & 20.7 & 4.7 & 0.1 & 8.7 & 0.0\end{array}$

$\begin{array}{llllll}4.9 & 24.1 & 3.1 & 2.2 & 37.0 & 1.1\end{array}$

$\begin{array}{llllll}0.2 & 1.7 & 0.01 & 0.1 & 4.3 & 0.0\end{array}$

$\begin{array}{llllll}1.1 & 8.6 & 0.2 & 0.0 & 0.0 & 0.0\end{array}$

$\begin{array}{llllll}0.2 & 3.4 & 0.02 & 0.0 & 2.2 & 0.0\end{array}$

$\begin{array}{llllll}0.0 & 0.0 & 0.0 & 0.2 & 10.9 & 0.03\end{array}$

$\begin{array}{llllll}0.5 & 8.6 & 0.1 & 0.9 & 28.3 & 0.4\end{array}$

$\begin{array}{llllll}0.1 & 1.7 & 0.0 & 0.0 & 0.0 & 0.0\end{array}$

$\begin{array}{llllll}0.2 & 3.4 & 0.01 & 0.3 & 17.4 & 0.1\end{array}$ 


\section{Highlights}

1. Natural diet analysis of T. mediterraneus juveniles associated with jellyfish.

2. T. mediterraneus mainly feeds on copepods and cladocerans.

3. Diet composition of T. mediterraneus depends on the host jellyfish.

4. Jellyfish species biology and behavior determine the diet of the hosted fish.

5. The hosted fish feed on the jellyfish tissue. 


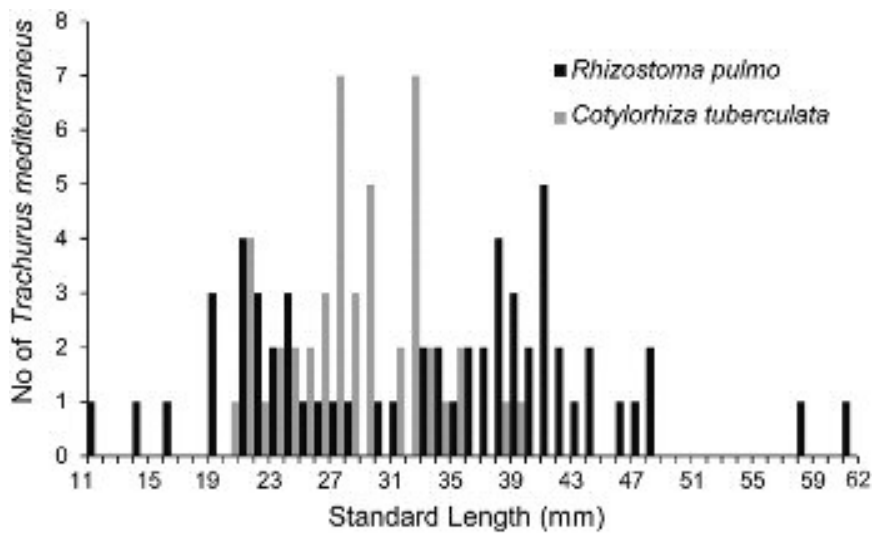

Figure 1 

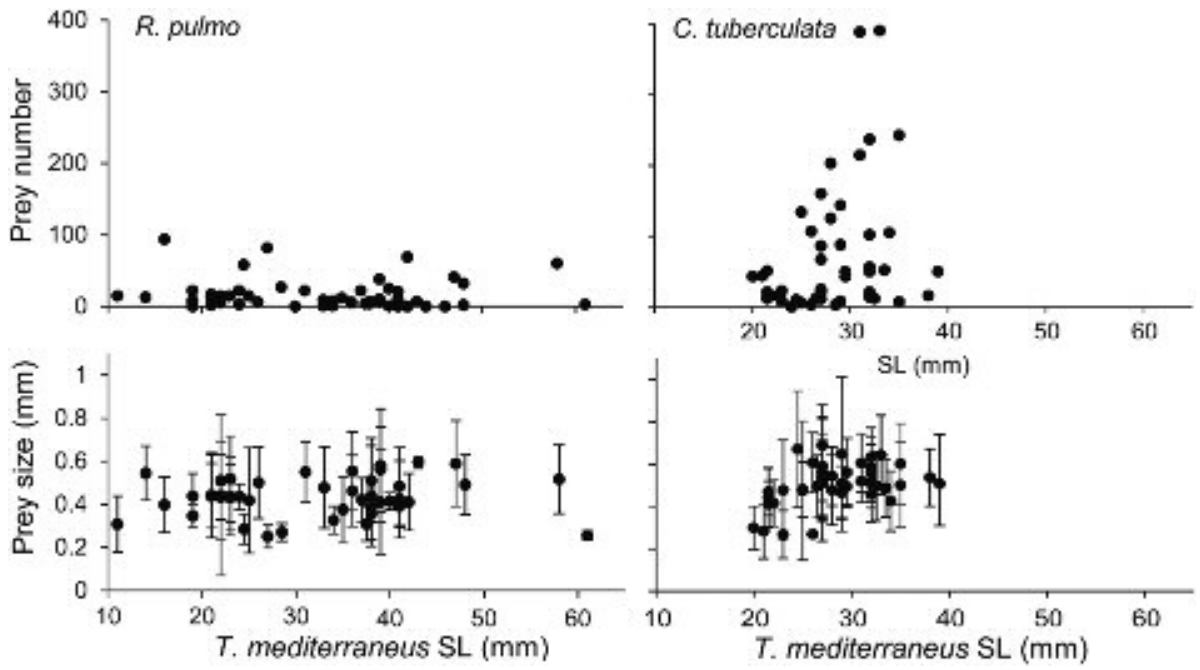

Figure 2 


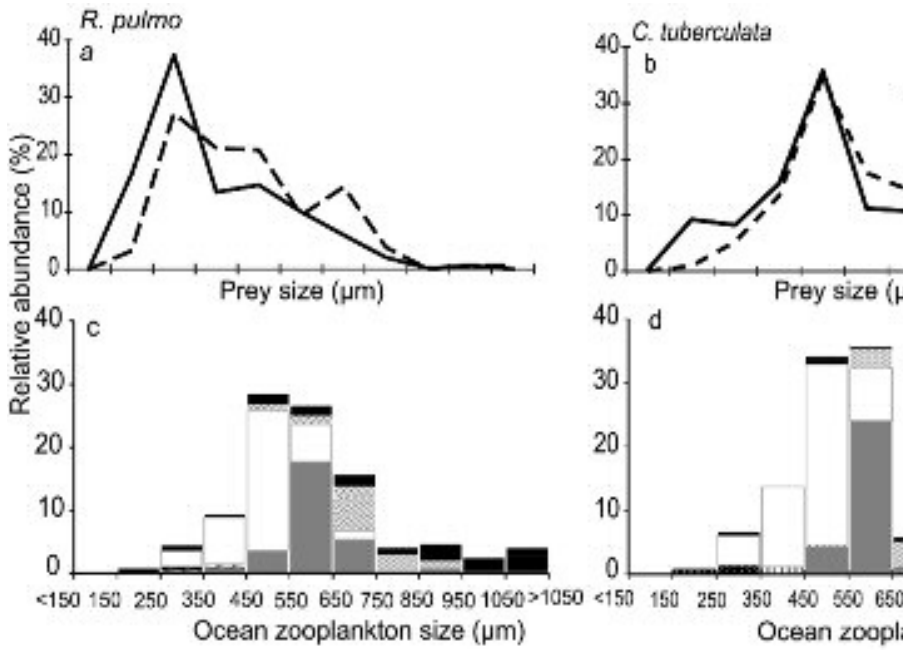

Figure 3 


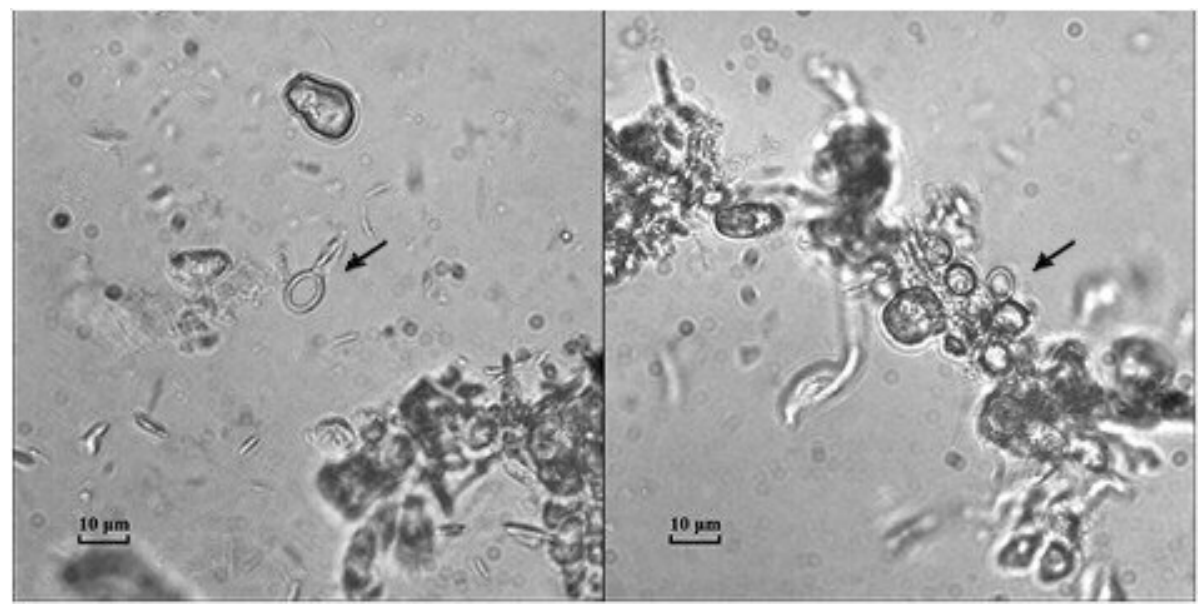

Figure 5 


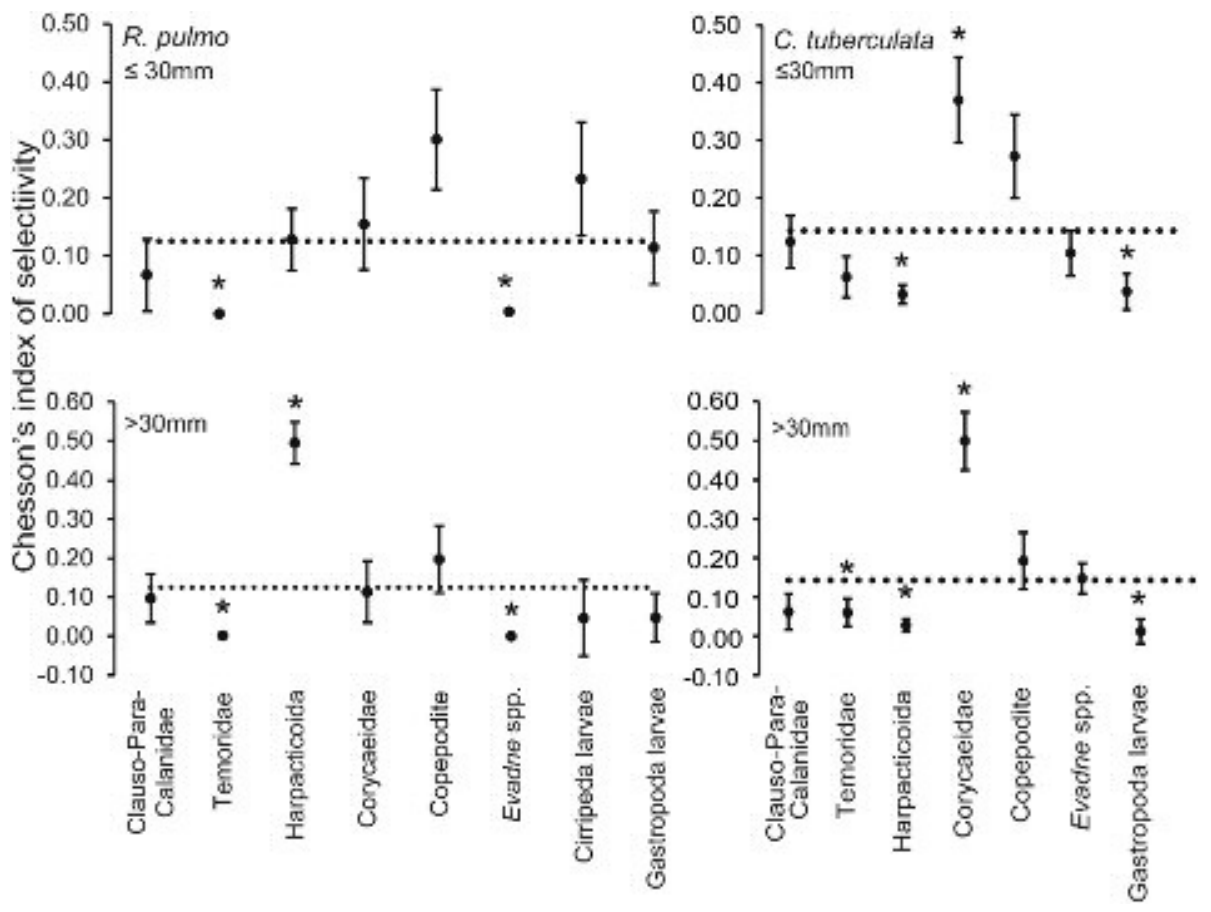

Figure 6 